\title{
PERKEMBANGAN PENGGUNAAN BETON BERTULANG DI INDONESIA PADA MASA KOLONIAL (1901-1942)
}

\section{THE DEVELOPMENT OF REINFORCED CONCRETE USED IN INDONESIA DURING COLONIAL PERIOD (1901-1942)}

\author{
Martha Setyowati \\ Alumnus Departemen Arkeologi, Fakultas Ilmu Budaya, Universitas Gadjah Mada, \\ Indonesia \\ palasara39@gmail.com
}

\begin{abstract}
The discovery of reinforced concrete became a major breakthrough in modern construction technology in the early $20^{\text {th }}$ century. In five decades reinforced concrete has developed rapidly and was used in almost all parts of the world. Reinforced concrete was first introduced in Indonesia during the colonial period. The used of reinforced concrete increased along with the construction growth in the Dutch East Indies. The used of reinforced concrete between 1901 and 1942 can be seen from the buildings and infrastructure that still exist today. However the development of reinforced concrete in Indonesia during colonial period not widely explored yet. Because of that this study aims to provide an overview of the development of reinforced concrete used during the colonial period using archaeological data and supported by historical data. This research uses secondary data sources obtained through literature study. Based on this research it can be concluded that the development of the reinforced concrete used in the colonial period showed the progress of construction technology as well as economic and social conditions at that time.
\end{abstract}

Keywords: Reinforced concrete; construction technology; construction material; colonial period

\section{ABSTRAK}

Penemuan beton bertulang menjadi terobosan besar dalam teknologi konstruksi modern pada awal abad ke-20. Dalam lima dasawarsa beton bertulang berkembang dengan cepat dan digunakan hampir di seluruh dunia. Beton bertulang pertama kali diperkenalkan di Indonesia pada masa kolonial. Penggunaan beton bertulang mengalami peningkatan seiring dengan meningkatnya kegiatan pembangunan di Hindia Belanda. Penggunaan beton bertulang yang antara 1901 sampai 1942 dapat dilihat dari bangunanbangunan dan infrastruktur yang masih ada sampai sekarang. Meskipun demikian perkembangan beton bertulang di Indonesia pada masa kolonial belum banyak dikaji. Oleh karena itu, penelitian ini bertujuan untuk memberikan gambaran perkembangan penggunaan beton bertulang pada masa kolonial dengan menggunakan data arkeologi dan didukung dengan data sejarah. Sebagian besar sumber data yang digunakan dalam penelitian merupakan data sekunder yang diperoleh melalui studi kepustakaan. Berdasarkan penelitian ini dapat disimpulkan bahwa perkembangan penggunaan beton bertulang di masa kolonial menunjukan kemajuan teknologi konstruksi sekaligus kondisi ekonomi dan sosial pada masa itu.

Kata Kunci: Beton bertulang; teknologi konstruksi; material konstruksi; masa kolonial

Artikel Masuk

Artikel Diterima
: 05-08-2019

: 21-10-2019 


\section{PENDAHULUAN}

Beton ${ }^{1}$ (concrete) telah menjadi material komposit yang paling banyak digunakan dalam industri konstruksi modern (Harrer dkk, 2017, hlm. 29). Penggunaan beton sebagai material konstruksi mulai meningkat setelah beton bertulang (reinforced concrete) dikembangkan pada abad ke-19. Seiring dengan penggunaan beton yang semakin luas, teknik konstruksi dan variasi beton terus berkembang. Selain beton bertulang, terdapat lebih dari dua puluh variasi beton seperti beton prategang (prestressed concrete), beton pracetak (precast concrete), beton ringan (light-weight concrete), beton siap cetak (ready mix concrete), beton polymer (polymer concrete) dan lainnya. ${ }^{2}$ Beton dan berbagai variasinya yang ada sekarang digunakan di hampir semua jenis konstruksi dari rumah sederhana, gedung bertingkat, jalan layang, jembatan, menara air, lapangan udara, dinding penahan tanah, terowongan, bendungan, kanal, tiang pancang, bantalan kereta api, pemecah gelombang, bahkan dalam pemugaran candi sebagai perkuatan struktur (van Romondt, 2009, hlm. 242-243).

Penggunaan beton sebagai material struktur telah berkembang sejak masa kekaisaran Romawi (27 SM - 476 M). Para ahli bangunan Romawi mengembangkan opus caementicum atau beton Romawi (roman concrete), yang merujuk pada material sekaligus teknik konstruksi dengan cara menuang material komposit pada cetakan (Heinemann, 2013, hlm. 7). Perkembangan opus caementicum tidak terlepas dari pengetahuan material, salah satunya adalah pembuatan semen hidrolik (hydraulic cement) dari kapur. Orang Romawi mengembangkan semen hidrolik yang disebut semen Pozzolana (Pozzoloanic cement). Mereka menggunakan kapur hidrolis ${ }^{3}\left(\mathrm{Ca}(\mathrm{OH})_{2}\right)$ yang dicampur dengan abu vulkanik atau Pozzolana yang diperoleh di dekat Pulau Pozzuoli, Napoli, Italia. Pozzolana mengandung silika $\left(\mathrm{SiO}_{2}\right)$ dan alumina $\left(\mathrm{Al}_{2} \mathrm{O}_{3}\right)$ yang cukup tinggi, sehingga memberikan kekuatan lebih pada struktur yang dibangun. Selain semen Pozzolana, mereka menambahkan pecahan bata merah dan batu alam sebagai agregat.

Bukti arkeologis penggunaan opus caementicum dapat dilihat dari tinggalan struktur-struktur Romawi yang masih ada sampai sekarang seperti amphitheater, pantheon, aquaduk, viaduk, bendungan dan struktur lainnya. Pengaruh kekaisaran Romawi yang semakin lemah pada awal abad ke-5 M menjadi awal dari berakhirnya kekaisaran ini sekaligus perkembangan opus caementicum. Meskipun teknik pembuatan semen hidrolik dikenal secara lokal di bekas wilayah kekaisaran Romawi di Eropa, tidak ada pengembangan beton lebih lanjut sampai abad ke-18 (Reed, dkk, 2008, hlm. 6-7). Beton yang berkembang selama kurun waktu tersebut adalah beton tanpa perkuatan (unreinforced concrete atau mass concrete) yang penggunaannya untuk struktur bangunan masih terbatas. Beton tanpa tulangan biasanya digunakan untuk struktur-struktur yang berkaitan dengan air seperti di Inggris, Skotlandia

\footnotetext{
${ }^{1}$ Istilah béton diperkenalkan oleh insinyur Perancis bernama B.F. de Bélidor dalam publikasinya L'architecture hydraulique pada tahun 1818. Sementara itu, istilah concrete berasal dari bahasa latin concrescere yang berarti tumbuh bersama.

2 Sumber: https://theconstructor.org/concrete/types-concrete-applications/19779/

${ }^{3}$ Kapur hidrolis atau slaked lime $\left(\mathrm{Ca}(\mathrm{OH})_{2}\right)$ adalah kapur tohor atau quicklime $(\mathrm{CaO})$ yang bereaksi dengan air $\left(\mathrm{H}_{2} \mathrm{O}\right)$. Kapur tohor dihasilkan dari pembakaran kapur mentah $\left(\mathrm{CaCO}_{3}\right)$.
} 
dan Belanda. Beton kembali berkembang pada abad ke-19 bersamaan dengan berkembangnya industri semen Portland (Portland cement). ${ }^{4}$

Beton (modern) maupun opus caementicum pada dasarnya menggunakan prinsip kerja yang sama, yaitu memanfaatkan kerja semen sebagai bahan pengikat (binder) yang dapat mengeras bila bergabung (hidrasi) dengan air. Semen Portland menjadi bahan pengikat yang umumnya digunakan pada beton modern. Bahan pengisi atau agregat (aggregate) yang terdiri dari agregat halus (fine aggregate) berupa pasir dan agregat kasar (coarse aggregate) berupa batu pecah (split) atau kerikil diperlukan selain bahan pengikat/semen Portland (Frick, dkk, 2007, hlm. 97). Agregat merupakan komponen yang penting karena mempengaruhi sifat dan daya tahan beton, biasanya agregat mengisi 75\% dari komposisi beton. Semen Portland dan air akan mengisi celah-celah dan mengikat agregat. Bahan-bahan tersebut yang telah dicampur selanjutnya membentuk material padat seperti batu setelah proses selesai hidrasi.

Perkembangan beton modern sampai sekarang tidak terlepas dari peran inventor-inventor yang mengembangkan beton bertulang sebagai material struktur. ${ }^{5}$ Menyadari beton memiliki kekuatan tekan (compression strength) tinggi, namun memiliki kekuatan tarik (tensile strength) relatif rendah, dikembangkan beton yang diberi perkuatan (reinforcement) dengan menambahkan tulangan (reinforcing bar). Beton yang kemudian dikenal sebagai beton bertulang diberi perkuatan dari batang besi atau baja di untuk memberikan kekuatan tarik (McCormac, 2004, hlm. 1-2). Penambahan tulangan di dalam massa beton tidak hanya memberi kekuatan tarik, tetapi juga memungkinkan beton bertulang untuk dibuat dalam bentangan horisontal, bahkan dirancang dalam sebuah struktur monolitik. Elemenelemen struktur seperti pondasi, kolom, balok dan pelat dapat dibuat menjadi struktur rangka beton bertulang sehingga beban konstruksi dibagi secara merata (Gambar 1).

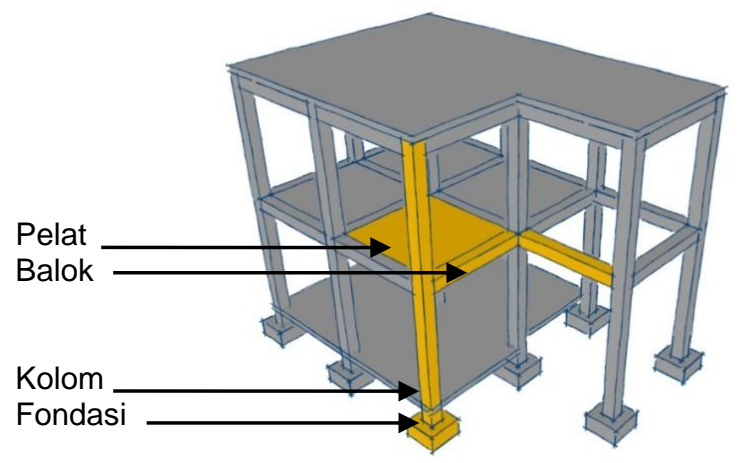

Gambar 1. Elemen-Elemen Struktur Beton Bertulang (Sumber: Penulis 2019)

\footnotetext{
${ }^{4}$ Joseph Apsdin merupakan seorang ahli bangunan yang menemukan formula semen Portland. Penemuannya dipatenkan pada 1824 dan mulai diproduksi secara massal. Formula semen Portland terus dimodifikasi dan dikembangkan oleh inventor-inventor lain untuk meningkatkan kekuatannya. Sampai sekarang semen Portland telah berkembang menjadi beberapa macam tipe (formula) dengan spesifikasi yang berbeda-beda. ${ }^{5}$ Beberapa inventor yang mulai mengawali pengembangan beton bertulang diantaranya adalah William B. Wilkinson (1819-1901), François Coignet (1844-1888), Joseph Monier (1823-1906), Thaddeus Hyatt (1816-1901), Ernest L. Ransome (1852-1917) dan François Hennebique (1842-1921).
} 
Pembagian beban konstruksi yang merata memungkinkan elemenelemen struktur untuk dibuat dalam dimensi yang lebih ramping, bentangan yang besar, kantilever 6 yang lebar dan tampak bermain dengan gravitasi (melayang) (Gambar 2 dan 3) (Heinemann, 2013, hlm. 42), sehingga beton bertulang dapat digunakan lebih luas untuk berbagai jenis struktur. Kehadiran beton bertulang mulai menggeser penggunaan material konstruksi konvensional seperti kayu. Perkembangan beton bertulang secara tidak langsung turut berdampak besar terhadap perkembangan arsitektur modern.

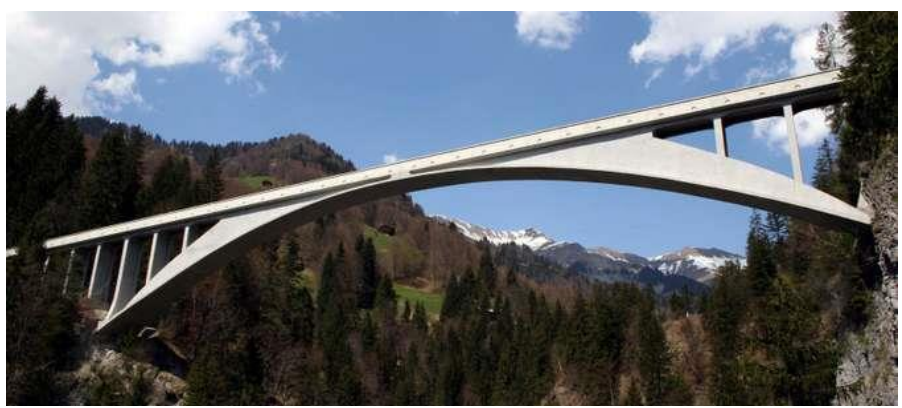

Gambar 2. Salginatobel Bridge, Switzerland (1930)

Jembatan dari beton bertulang dengan lebar 3,5 m, panjang $132,3 \mathrm{~m}$ dan bentangan $90 \mathrm{~m}$. (Sumber: britannica.com)
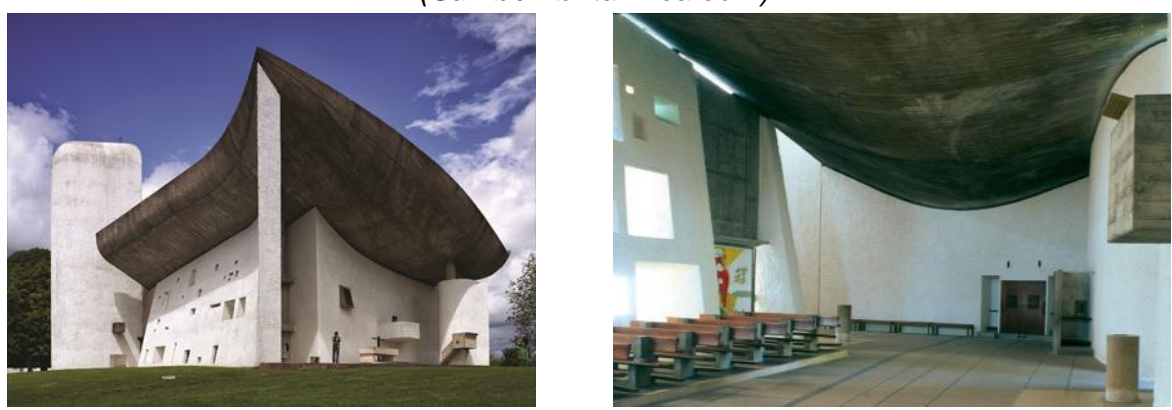

Gambar 3. Chapelle Notre Dame du Haut, Ronchamp, France (1950-1955)

Atap lengkung dari beton bertulang tampak seperti melayang tanpa disokong banyak kolom (Sumber: fondationlecorbusier.com)

Beton bertulang dengan cepat menjadi material konstruksi yang populer selama paruh pertama abad ke-20, terutama di Eropa dan Amerika Serikat. Beton bertulang di Eropa salah satunya dipopulerkan oleh François Hennebique dengan slogan "Plus d'incendies désastreux" tidak ada lagi kebakaran yang menimbulkan bencana. ${ }^{7}$ Perusahaan konstruksi yang didirikannya pada tahun 1896 berkembang pesat. Sekitar tahun 1910-an perusahaannya telah memiliki lebih dari tiga puluh agen yang tersebar di lebih dari dua puluh negara dan menghasilkan lebih dari 25.000 struktur yang dirancang dengan sistem Hennebique. Beton bertulang menjadi semakin populer di Amerika Serikat setelah Gempa Bumi San Fransicso 1906. Beberapa struktur dari beton bertulang, diantaranya bangunan Leland Stanford Museum dan Alvord Lake Bridge yang

${ }^{6}$ Elemen struktur seperti balok atau pelat yang menonjol keluar yang hanya disokong pada salah satu sisinya sehingga terlihat menggantung.

${ }^{7}$ Sumber: http:// parisisinvisible.blogspot.com/2011/10/where-systeme-hennebique-lives-on.html 
dirancang Ernest L. Ransome selamat dari guncangan 8 skala Richter yang disusul kebakaran (McCormac, 2004, hlm. 5-6).

Kemampuan struktur beton bertulang yang tahan gempa (kokoh) dan tahan api dalam Gempa Bumi San Fransisco 1906 menjadi berita besar pada waktu itu, termasuk di Hindia Belanda ${ }^{8}$. Berita perkembangan beton bertulang yang berlangsung di Eropa telah muncul di beberapa surat kabar yang terbit di Hindia Belanda ${ }^{9}$ sebelum peristiwa tersebut. Beton bertulang pertama kali digunakan oleh Dinas Manajemen Air ${ }^{10}$ dalam pembangunan sebuah jembatan yang berada di Cirebon pada tahun 190611. Bangunan beton bertulang pertama yaitu pabrik air mineral Hygeia dibangun di Semarang pada tahun 1908. ${ }^{12}$ Bangunan ini sampai sekarang masih berdiri di antara lapak pedagang Pasar Ikan Hias Jurnatan, namun kondisinya tampak tidak terawat (Gambar 4).
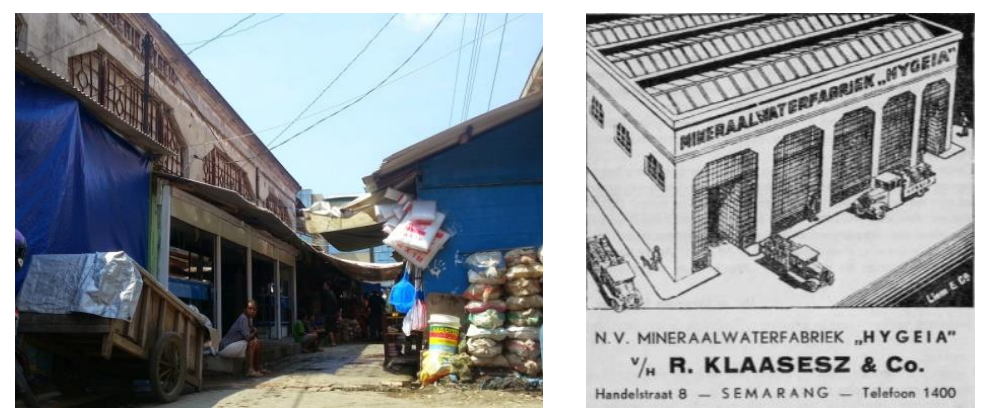

Gambar 4. Bangunan Pabrik Air Mineral Hygeia (1908)

Kiri: Kondisi bangunan sekitar tahun 2015 - Gambaran bangunan pabrik Hygeia dalam iklan (Sumber: raisoanteng.blogspot.com; yogifajri.blogspot.com)

Pertumbuhan ekonomi antara tahun 1910-an sampai 1920-an, memicu kegiatan pembangunan di Hindia Belanda. Hal ini tidak terlepas dari kebijakan Sistem Desentralisasi yang diberlakukan Pemerintah Kolonial pada tahun 19051906. Pembentukan kota praja (gemeente) berdampak pada meningkatnya kebutuhan bangunan untuk kantor-kantor pemerintahan dan dinas pemerintah, maupun fasilitas publik seperti rumah sakit, sekolah, pasar, rumah potong, serta fasilitas pertanian. Kebutuhan bangunan komersial turut meningkat seiring dengan berkembangnya kegiatan ekonomi swasta, sehingga banyak perusahaan swasta dan bank yang membuka kantor cabang di kota-kota Hindia Belanda (Koesno, 2009, hlm. 180). Maraknya kegiatan pembangunan di Hindia Belanda membuka kesempatan perusahaan-perusahaan konstruksi untuk berkembang, yang kemudian menjadi cikal bakal industri konstruksi di Indonesia (pasca kemerdekaan sampai sekarang).

Bersamaan dengan mulai berakhirnya masa kolonial, dalam rentang tahun 1910-an sampai 1940-an tidak sedikit struktur-struktur beton bertulang

\footnotetext{
8 Untuk memudahkan penyebutan, penulis tetap menggunakan nama Hindia Belanda untuk merujuk Indonesia pada masa kolonial.

${ }^{9}$ De Locomotief: Samarangsch handels- en advertentie-blad, "Nieuw Metsel-Materiaal", 24 Desember 1869; Java-bode: nieuws, handels- en advertentieblad voor Nederlandsch-Indie, "Beton", 2 Juni 1870.

${ }^{10}$ Dinas Manajemen Air - Waterstaat Dienst merupakan bagian dari Departemen Pekerjaan Umum dan Sipil Departement van Burgerlijke Openbare Werken.

${ }^{11}$ Het nieuws van den dag voor Nederlandsch-Indie," "De eerste brug van gewapend beton", 14 Mei 1906.

12 Soerabaijasch handelsblad, "De nieuwe mineraalwaterfabriek Hygeia", 28 Agustus 1908.
} 
yang dibangun di Indonesia. Peninggalan arkeologis baik bangunan maupun non-bangunan (infrastruktur) beton bertulang dari kurun waktu tersebut sebagian diantaranya sekarang telah berstatus Cagar Budaya, meskipun demikian belum banyak catatan mengenai perkembangannya. Melalui tulisan ini penulis mengkaji perkembangan penggunaan beton bertulang di Indonesia pada masa kolonial dengan menggunakan data arkeologi dan sejarah.

\section{METODE PENELITIAN}

Penelitian ini menggunakan sumber data sekunder yang diperoleh melalui studi kepustakaan. Data kepustakaan yang digunakan diantaranya adalah buku-buku referensi, disertasi, serta artikel-artikel dari jurnal, surat kabar, internet, serta foto-foto lama dan baru (Sukendar, dkk., 1999, hlm. 20-21). Mengingat keterbatasan waktu dan ruang dan banyaknya data yang tersedia, tidak semua data dapat ditampilkan dalam tulisan ini, sehingga digunakan metode purposive sampling. Tanpa meninggalkan kajian arkeologi itu sendiri yang didukung dengan sumber terulis (Gambar 5), objek-objek bangunan maupun non bangunan seperti jembatan atau bendungan yang digunakan sebagai sampel dalam penelitian ini merupakan objek-objek yang masih ada di Indonesia sampai sekarang dari rentang tahun 1901 sampai dengan 1942.
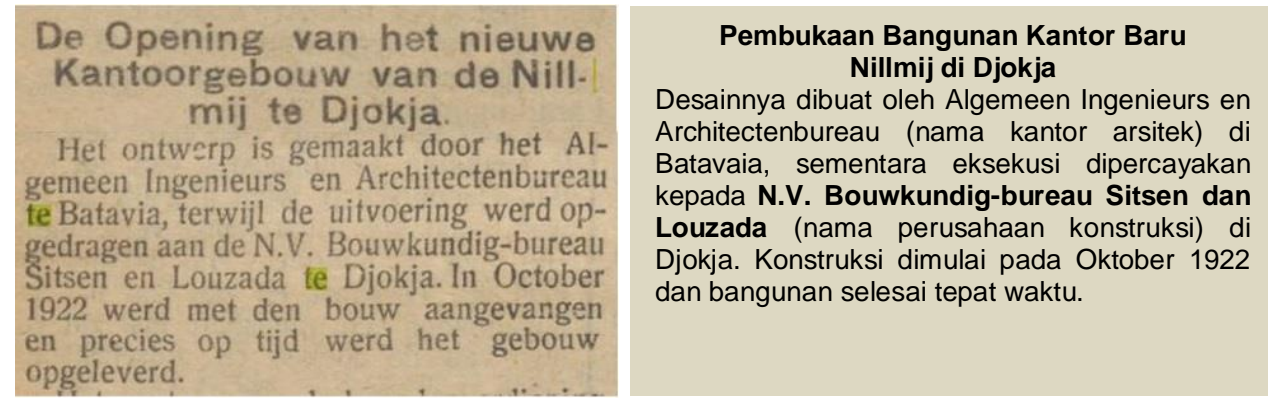

Gambar 5. Potongan Berita Pembukaan Kantor NILLMIJ di Djokja dan Terjemahannya (Sumber: Indische Courant, 11 Februari 1924)

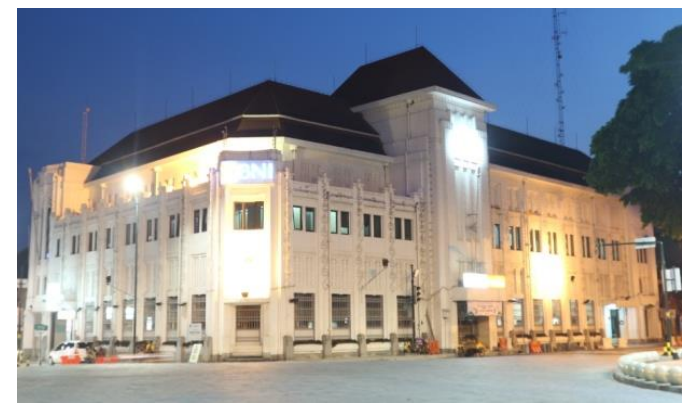

Gambar 6. Bangunan Kantor Asuransi NILLMIJ di Yogyakarta - Sitsen en Louzada (1922-1924) (Sumber: Dokumentasi Penulis 2018)

Penggunaan foto-foto disamping untuk memberikan gambaran yang lebih jelas kepada pembaca, digunakan untuk melakukan observasi tidak langsung terhadap objek yang diteliti. Penulis tetap menggunakan nama awal objek dalam deskripsi, meskipun objek-objek penelitian ini sekarang telah berganti nama atau fungsi. Informasi dari sumber tertulis yang terkait dengan 
pembangunan seperti nama eksekutor (kontraktor) dan tahun pembangunan tidak semuanya dapat ditampilkan secara utuh, karena itu informasi tersebut dicantumkan secara singkat di bagian informasi gambar (Gambar 6).

\section{HASIL PENELITIAN}

\section{Struktur-Struktur Beton Bertulang Dari Masa Kolonial}

Penggunaan beton bertulang masih relatif terbatas antara tahun 1901 sampai 1910. Informasi penggunaan beton bertulang dalam kurun waktu tersebut belum banyak diperoleh, selain jembatan di Cirebon (1907) dan pabrik Hygeia di Semarang (1908). Memasuki tahun 1910-an mulai terlihat peningkatan dalam penggunaan beton bertulang. Perkembangan penggunaan beton bertulang dapat dilihat dari stuktur-struktur beton bertulang yang terdiri dari bangunan dan infrastruktur yang dibangun antara tahun 1911 sampai 1942.

\section{Bangunan perkantoran}

Kantor Nederlandsch Indische Levensverzekering en Lijfrente Maatschappij van 1859 (NILLMIJ) di Weltevredren, Batavia (sekarang Sawah Besar, Jakarta Pusat) merupakan salah satu bangunan beton bertulang pertama yang dibangun antara tahun 1910 sampai 1911 (Akihary, 1990, hlm. 41)13. Arsitek P. A. J. Moojen bersama S. Snuyf dan W. Elenbaas merancang bangunan ini dalam gaya indische bouwstijl. Bangunan ini mengawali tren bangunan modern tidak hanya dalam hal arsitektur, namun juga dalam teknik dan material konstruksi (Gambar 7.). Bangunan yang kini digunakan sebagai kantor pusat asuransi Jiwasraya ini direstorasi pada tahun 2005, ketika dinding dikupas ditemukan tulangan besi berdiameter 18-20 milimeter. ${ }^{14}$

NILLMIJ ${ }^{15}$ kembali membangun kantor cabang di Semarang pada tahun 1916. Lokasi kantor NILLMIJ di Semarang berada di Heerenstraat (sekarang Letjend. Soeprapto, Kota Lama) tepat berseberangan dengan Gereja Blenduk. Bangunan bergaya art deco ini dirancang arsitek H. T. Karsten dan eksekusinya diserahkan kepada Hollandsche Beton Maatschappij (H.B.M.). Bangunan ini memiliki denah berbentuk $\mathrm{L}$ dengan pintu masuk utama di bagian sudut yang ditandai dengan atap berbentuk kubah segi delapan (Gambar 8).

Salah satu bangunan di Bandung yang memiliki kisah menarik dalam peristiwa Bandung Lautan Api, 23 Maret 1946 adalah Kantor Pos dan Telegraf. Bangunan bergaya art deco ini semula hendak turut dibakar dalam peristiwa tersebut, namun bangunan beton bertulang ini sulit terbakar meskipun sudah disiram bensin dan disulut api berkali-kali. ${ }^{16}$ Bangunan rancangan arsitek dari

\footnotetext{
${ }^{13}$ Dalam bukunya Akihary menyebutkan bahwa bangunan kantor NILLMIJ di Weltevedren dibangun pada tahun 1909, namun berdasarkan iklan di surat kabar Het nieuws van den dag voor Nederlandsch-Indië pada 12 April 1910, bangunan kantor NILLMIJ di Weltevedren masih dalam tahap penawaran.

${ }_{14}$ Sumber: http://tarulh.com/2016/04/04/moojen-mengubah-batavia/

${ }^{15}$ NILLMIJ, perusahaan asuransi terbesar masa kolonial, juga membangun kantor cabang di Bandung (1920), Medan (1922) dan Jogja (1924). Setelah dinasionalisasi pada tahun 1960, kantor-kantor NILLMIJ di Indonesia menjadi kantor PT. Asuransi Jiwasraya.

${ }^{16}$ Sumber: http://www.infobdg.com/v2/kantor-pos-besar-bandung-sejarah-yang-tidak-bisa-dihancurkan/
} 
Departement van Burgerlijke Openbare Werken (B.O.W.) ${ }^{17}$ - J. Van Gendt yang kini dikenal sebagai Kantor Pos Besar Bandung pada akhirnya tidak terbakar dan masih berdiri kokoh hingga sekarang (Gambar 9).

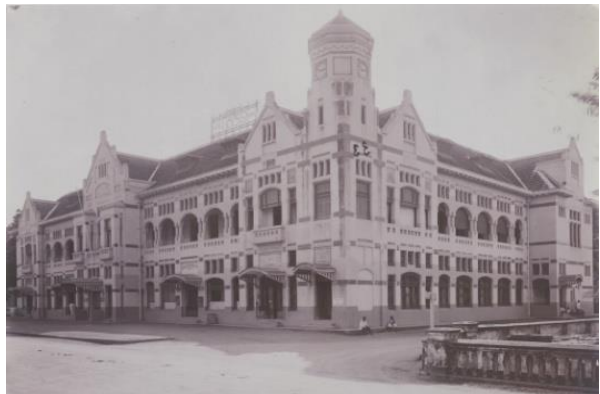

Gambar 7. Kantor NILLMIJ di Weltevedren (1910-1911)

(Sumber: colonialarchitecture.eu)

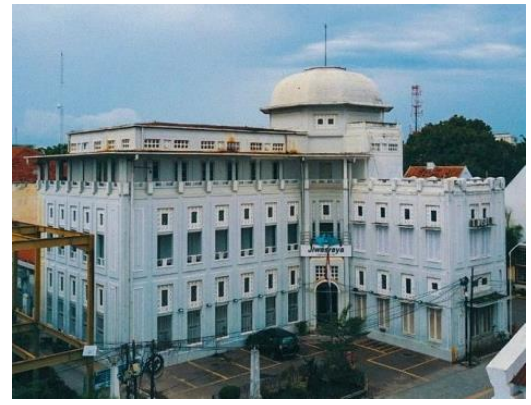

Gambar 8. Kantor NILLMIJ di Semarang (1916) - H.B.M

(Sumber: Dokumentasi Penulis 2019)

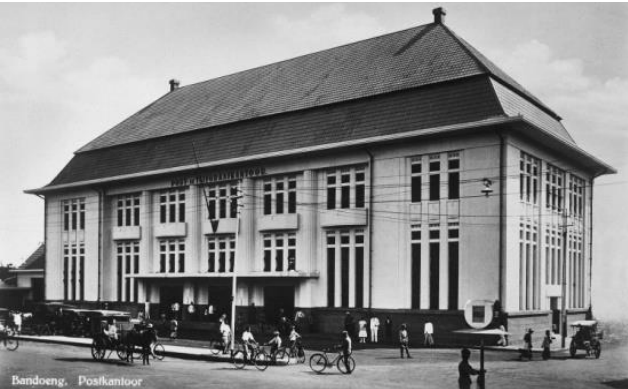

Gambar 9. Kantor Pos dan Telegraaf (1928) - H.B.M (Sumber: colonialarchitecture.eu)

Memasuki tahun 1930-an gaya de stijl mulai bermunculan di Hindia Belanda, salah satunya bangunan Kantor Gubernur Jawa Timur. Bangunan ini dirancang arsitek dari Department van B.O.W. - W. Lemei bersama H. A. Breuning dan W. B. Carmiggelt, sementara eksekusinya ditangani Nederlandsche Aanemings Maatschappij (NEDAM). Bangunan ini seluruhnya menggunakan atap datar (dak beton), meskipun berada di daerah beriklim tropis dengan curah hujan dan kelembaban yang tinggi. Oleh karena itu, di bawah plat atap diberi lubanglubang sebagai ventilasi silang untuk mengurangi kelembaban. Bangunan ini masih digunakan sebagai Kantor Gubernur Jawa Timur sampai sekarang (Gambar 10).

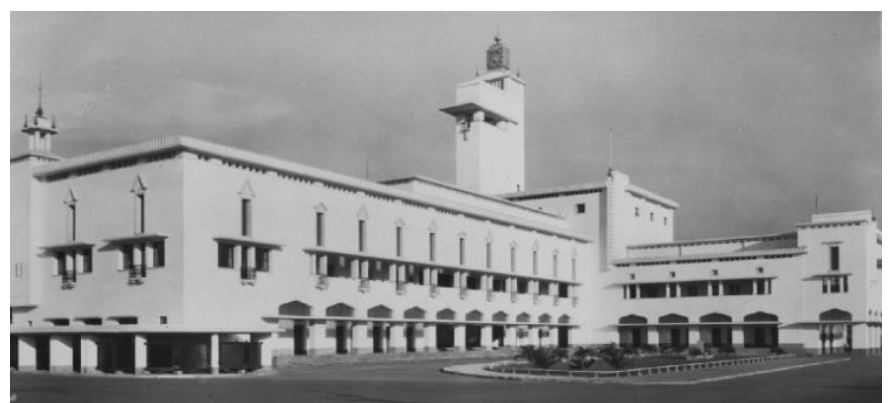

Gambar 10. Kantor Gubernur Jawa Timur (1931) - NEDAM (Sumber: colonialarchitecture.eu)

${ }^{17}$ Departement van Burgerlijke Openbare Werken (B.O.W.) - Departemen Pekerjaan Umum dan Sipil. Sejak 1909 B.O.W. telah memiliki seksi arsitektur yang melakukan perancangan untuk bangunan-bangunan pemerintah. 


\section{Bangunan komersial}

Hadirnya bangunan-bangunan usaha komersial yang menampilkan modernisme seperti toko, hotel dan bioskop tidak terlepas dari perkembangan penggunaaan beton bertulang. Bangunan-bangunan modern tidak sekedar kebutuhan pada waktu itu tetapi juga bagian dari iklan (Koesno, 2012, hlm. 23-25). Salah satu hotel tertua di Bandung "Grand Hotel Preanger" bahkan membangun ulang bangunan lama bergaya indische empire menjadi bangunan tiga lantai yang dirancang arsitek C. P. Wolff Schoemaker dalam gaya art deco (1929) (Gambar 11). Bangunan ini masih digunakan sebagai hotel sekarang menjadi "Prama Grand Preanger".
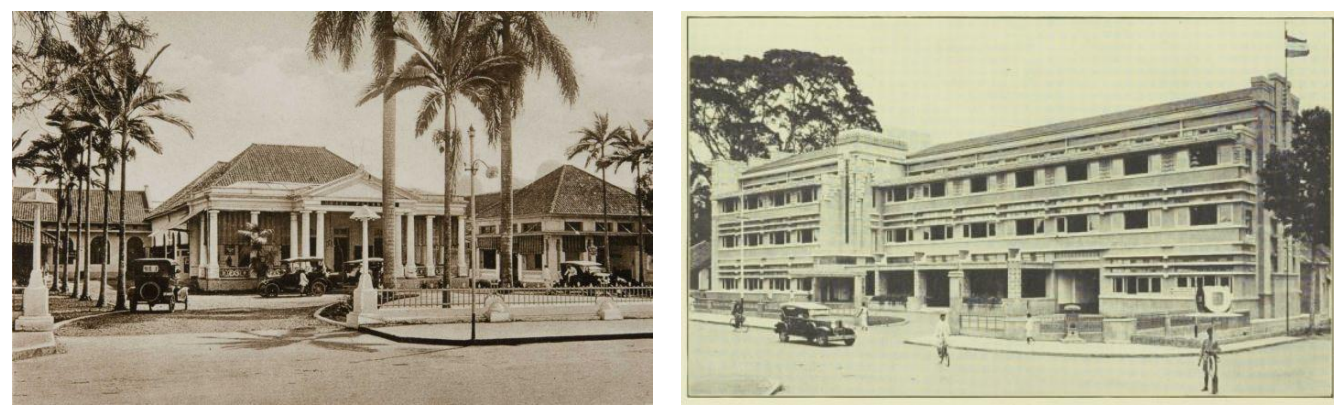

Gambar 11. Hotel Preanger - sebelum direnovasi (1920-an) dan setelah direnovasi (1929) (Sumber: colonialarchitecture.eu)

Penggunaan beton bertulang dalam bangunan komersial secara tidak langsung terlihat dari bangunan-bangunan beratap datar (dak beton) yang umum dijumpai di deretan pertokoan masa kolonial seperti kawasan pertokoan di Kayu Tangan, Malang. Kawasan yang kini dikenal dengan perempatan Rajabally tersebut terdapat bangunan kembar beratap datar yang dahulu merupakan toko perhiasan (juwelier) "Tan", sementara bangunan kembar di seberangnya toko buku (boekhandel) "Sluyter - G. C. T. van Dorp". Bangunan tersebut dirancang arsitek lokal, K. H. G. Bos sementara eksekusinya dikerjakan Algemeen Ingenieurs en Architecten-bureau (A.I.A.) (Gambar 12).

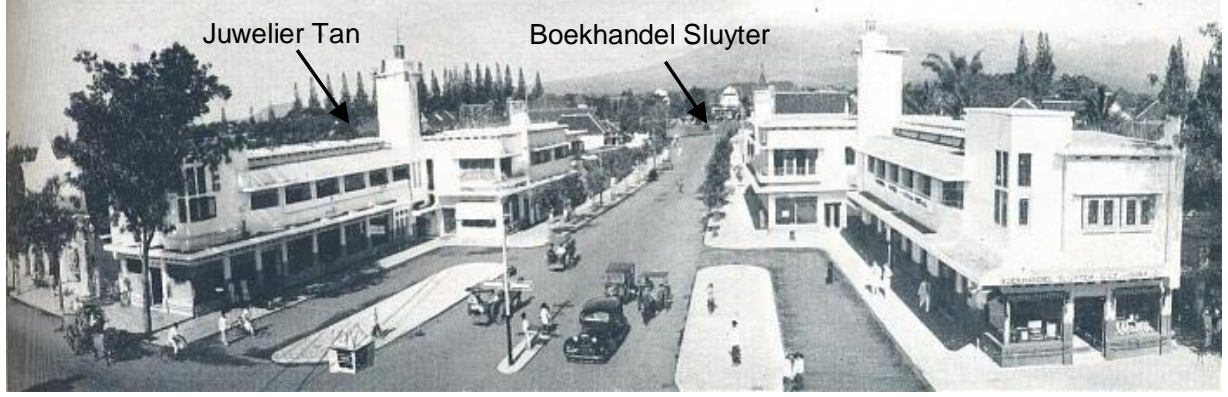

Gambar 12. Toko Perhiasan Tan - Toko Buku Sluyter - A.I.A. (1938) (Sumber: wikimapia.org)

\section{Bangunan publik}

Bangunan publik seperti pasar mulai dibangun menggunakan beton bertulang di masa kolonial. Beton bertulang merupakan material yang tepat untuk pasar, selain tidak mudah terbakar dari sisi higienitas material ini mudah dibersihkan dan tidak berjamur. Bandung menjadi kota pertama yang memiliki pasar modern dari beton bertulang. Pasar tersebut adalah pasar Kosambi, pasar 
Andir dan pasar Baroe yang dibangun Pemerintah Kota Bandung antara tahun 1915 sampai 1916, seluruh eksekusinya diserahkan kepada H.B.M. ${ }^{18}$ Pasar modern dari beton bertulang tidak hanya dibangun di Bandung, tetapi juga di kota-kota lain seperti Semarang, Batavia, Surabaya, Malang dan Palembang.

Pasar dari beton bertulang pertama di Semarang dibangun pada tahun 1916 (Gambar 13) adalah pasar Peterongan yang berada di antara Sompok dan Lampersariweg. Pasar Peterongan awalnya merupakan pasar swasta yang diambil alih Pemerintah Kota Semarang. Bangunan pasar yang awalnya semi permanen dibangun menjadi bangunan permanen dari beton bertulang di atas seluas $2500 \mathrm{~m}^{2}$ (Semarang, 1931, hlm. 181). Bangunan pasar Peterongan sempat dibongkar pada tahun 2015 untuk didirikan bangunan baru, namun rencana ini dibatalkan. Pasar Peterongan direvitalisasi kembali sesuai bangunan lamanya pada tahun 2016.

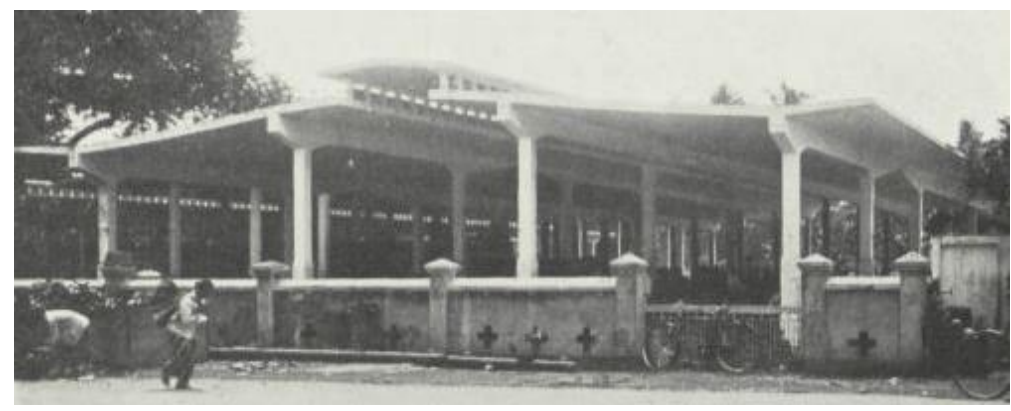

Gambar 13. Pasar Peterongan, Semarang - H.B.M. (1916)

(Sumber: Gedenkboek der Gemeente Semarang 1906-1931)

Bangunan publik dari beton bertulang lainnya adalah bangunan stasiun, salah satunya Stasiun Batavia Zuid milik Staatsspoorwagen (S.S.). Bangunan stasiun bergaya art deco ini dirancang oleh arsitek F. J. L. Ghijsels (A.I.A.). Bangunan utama dibangun dari beton bertulang, sementara bagian emplasemen menggunakan konstruksi rangka baja. Penggunaan beton bertulang memungkinkan rangka penopang atap di bangunan utama dirancang dalam bentuk lengkung yang sekaligus menjadi fasad dari bangunan ini (Gambar 14). Stasiun Batavia Zuid yang sekarang dikenal sebagai Stasiun Jakarta Kota mulai beroperasi pada 8 Oktober 1929 sampai sekarang. ${ }^{19}$
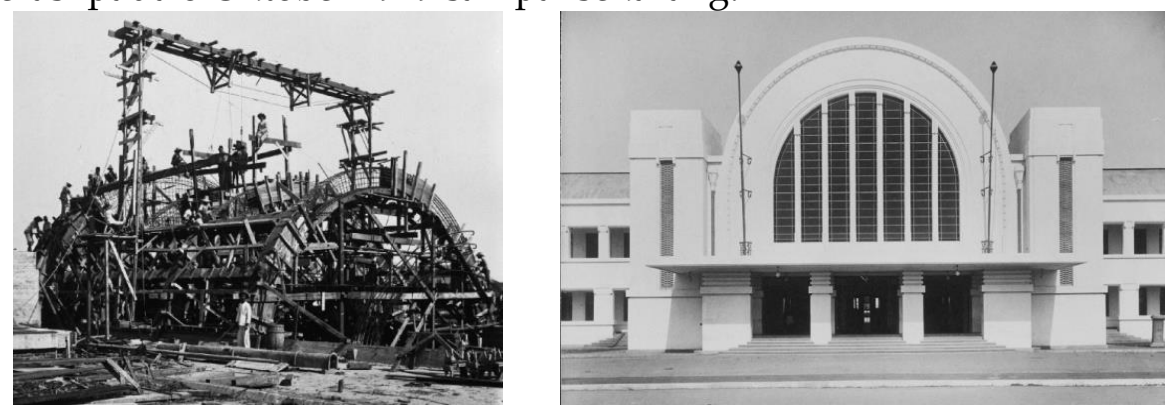

Gambar 14. Stasiun Batavia Zuid - Firma W. Elenbaas (1928-1929)

Kiri: Proses pemasangan bekisting

(Sumber: colonialarchitecture.eu)

${ }^{18}$ De Preanger Bode, "De Opening van Pasar Baroe", 7 September 1915; De Preanger Bode, "Gemeentewerken", 21 Oktober 1915.

${ }_{19}$ Bataviaasch nieuwsblaad, "Het New Station Batavia", 4 Oktober 1929; Bataviaasch nieuwsblaad 


\section{Bangunan rumah tinggal}

Bungalow atau rumah persisirahatan yang dibangun di kota atas menjadi tren yang muncul pada tahun 1920-an (Mrázek, 2006, hlm. 96-97). Bangunan peristirahatan yang masih ada sampai sekarang salah satunya adalah "Villa Isola" yang berada di Lembang, Bandung. Bangunan beton bertulang bergaya art deco ini dirancang arsitek C. P. Wolff Schoemaker. Penggunaan beton bertulang tidak hanya digunakan pada bangunan tetapi juga pada instalasi taman (Gambar 15). Memanfaatkan kemampuan beton bertulang yang bebas dibentuk sebagian besar bagian baik pada interior maupun eksterior dirancang dengan sisi-sisi lengkung. Bangunan Villa Isola sekarang digunakan sebagai gedung perkuliahan Universitas Pendidikan Indonesia.
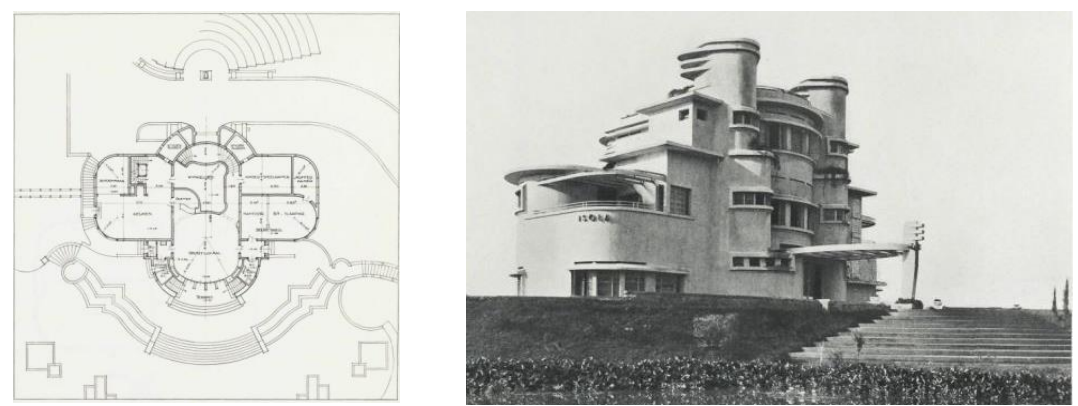

Gambar 15. Villa Isola, Bandung - A.I.A. (1933)

Kiri: Denah tapak Villa Isola

(Sumber: Moderning Architecture in Ned. Indie)

\section{Infrastruktur jembatan kereta}

Jembatan kereta pertama dari beton bertulang adalah jembatan Kalibelang (207 m) (Gambar 16) dan Kaliprupuk (52 m) yang berada di jalur Cirebon-Kroya. Pembangunan dua jembatan tersebut melibatkan H.B.M. dengan waktu konstruksi kurang dari dua tahun (1915-1916). ${ }^{20}$ Jembataan Kalibelang masih berdiri hingga sekarang, sementara jembatan Kaliprupuk lama sudah diganti dengan jembatan baru. Jembatan Kalibelang kini berdiri berdampingan dengan jembatan kereta baru yang dibangun pada tahun 2012 (Gambar 17).

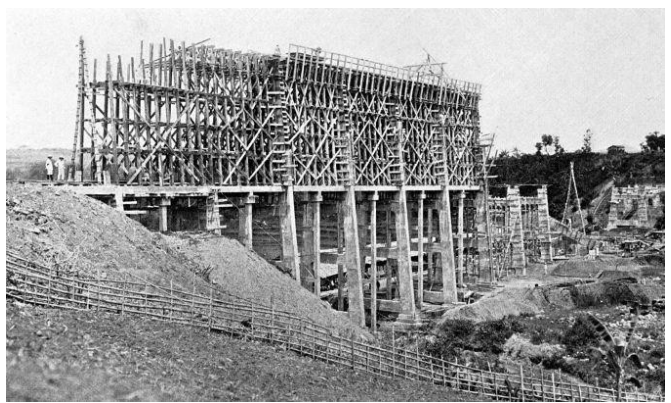

Gambar 16. Proses Konstruksi Jembatan Kereta Kalibelang (1915-1916) (Sumber: colonialarchitecture.eu)

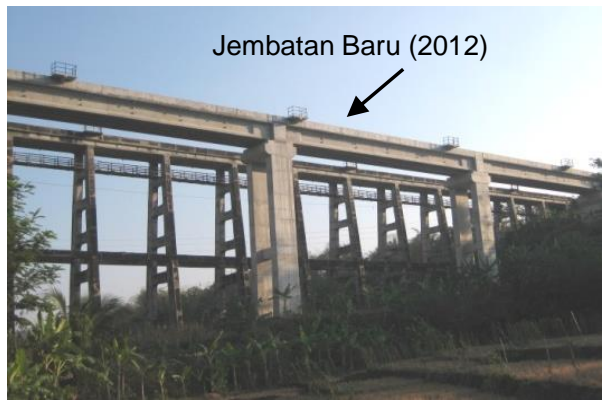

Gambar 17. Jembatan Kereta Kalibelang Lama (1916) dan Baru (2012) (Sumber: puadhasan.blogspot.com)

${ }^{20}$ Het nieuws van den dag voor Nederlandsch-Indie", "Gewapend Beton Spoorbruggen in de S.S. Lijnen", 24 November 1916, Bataviaasch nieuwsblad, "De Krojalijn", 6 Maret 1915. 


\section{Infrastruktur jembatan penyeberangan}

Jembatan beton bertulang dari masa kolonial yang masih tersisa sampai sekarang salah satunya adalah jembatan Kampung Tinggi di Buleleng, Bali (Gambar 18). Informasi mengenai pembangunan jembatan Kampung Tinggi tidak banyak diperoleh. Jembatan Kampung Tinggi memiliki kemiripan dengan jembatan Petissah (1938) di Medan yang dirancang tanpa kolom penyangga di bawahnya (Gambar 19).

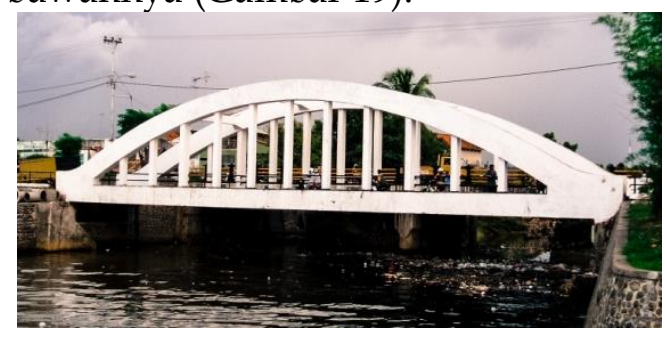

Gambar 18. Jembatan Kampung Tinggi (Sumber: kebudayaan.kemdikbud.go.id)

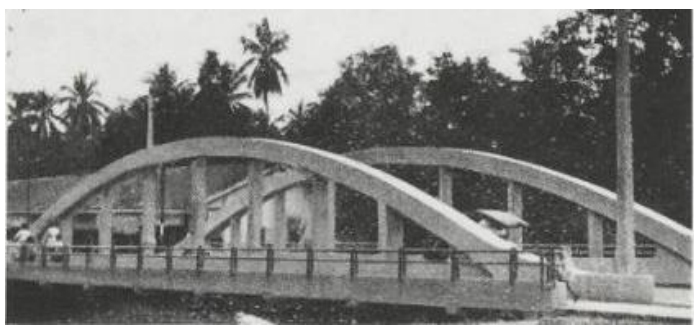

Gambar 19. Jembatan Petissah (Sumber: Locale Techniek, 1938)

\section{Infrastruktur bendungan}

Bendungan Tjitarorem yang kini lebih dikenal dengan "Bendungan Walahar" merupakan salah satu bendungan modern dari masa kolonial yang masih berfungsi sampai sekarang. Pembangunan bendungan Tjitaroem memakan waktu sekitar empat tahun dari tahun 1925 sampai tahun 1929. Dinas Manajemen Air melibatkan kontraktor Volker Aanneming Maatschappij dalam eksekusinya. ${ }^{21}$ Bendungan yang berada di Klari Karawang ini berfungsi mengatur laju air untuk mengairi pertanian di daerah Karawang yang terletak di antara sungai Citarum dan Cilamaya (Gambar 20).

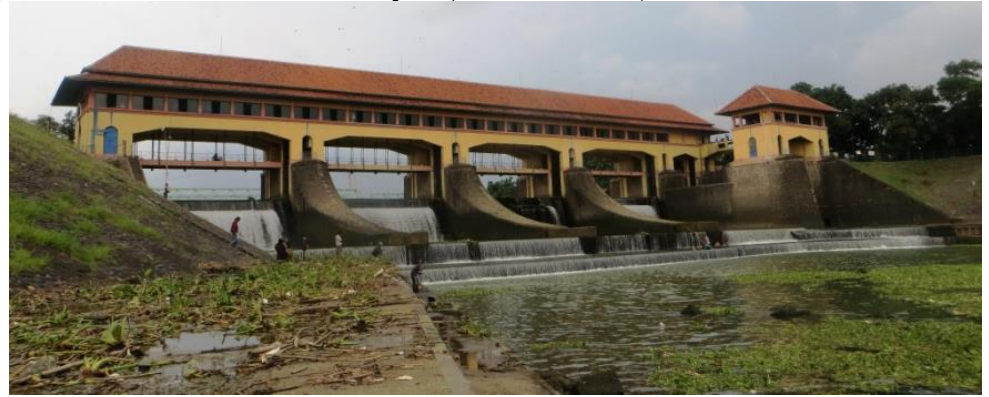

Gambar 20. Bendungan Tjitaroem (1925-1929) - Kondi tahun 2010 (Sumber: referensi.data.kemdikbud.go.id)

\section{Infrastruktur menara air}

Menara air yang berada di alun-alun Kota Magelang tidak sekedar landmark kota, namun juga bagian penting dari sejarah berdirinya Perusahaan Daerah Air Minum (PDAM) Kota Magelang. Pembangunan menara air dan jaringannya membutuhkan waktu sekitar tiga tahun (1920-1922). Menara air ini memiliki denah berbentuk lingkaran dengan tinggi 26, $1 \mathrm{~m}$ dan luas $526 \mathrm{~m}^{2}$. Tiga puluh dua kolom beton menopang bak penampungan air berkapasitas $1.750 \mathrm{~m}^{3}$.

${ }^{21}$ Het nieuws van den dag voor Nederlandsch-Indie", "Het ernstig defect in da Tjitaroemirrigatiewerken", 24 April 1929; Het nieuws van den dag voor Nederlandsch-Indie," "De irrigatie-werken bij Krawang", 28 April 1925; Het nieuws van den dag voor Nederlandsch-Indie,, "De irrigatie-werken bij Krawang", 2 April 1924. 
Menara air ini dilengkapi dengan 16 ruangan (1 sebagai pintu masuk) yang berada di bawah tiang penyangga. Ruangan tersebut diantaranya digunakan sebagai ruang laboratorium, ruang kontrol, ruang administrasi, ruang pelayanan (Wibowo, 2017, hlm. 170-171). Menara air ini masih mendistribusikan air bersih bagi penduduk Kota Magelang sampai sekarang (Gambar 21).

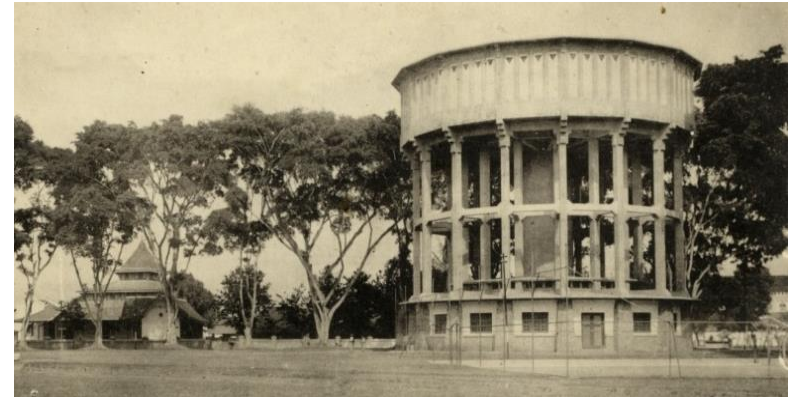

Gambar 21. Menara Air di Magelang (1920-1922)

(Sumber: colonialarchitecture.eu.)

\section{Infrastruktur kolam renang}

Bersamaan dengan berkembangnya aktivitas rekreasi (leisure) di kalangan orang Eropa pada tahun 1920-an, renang menjadi salah satu kegiatan rekreasi sekaligus olahraga yang populer. Sejumlah pemerintah kota bahkan membangun kolam renang sebagai bagian dari fasilitas kota karena begitu digemarinya olahraga ini. Kolam renang modern dari beton bertulang sudah mulai muncul pada awal tahun 1930-an di Hindia Belanda, meskipun teknologi ini baru dikembangkan di Amerika Serikat sekitar tahun 1920-an. ${ }^{22}$

Kolam renang modern pertama yang dibangun pada masa kolonial salah satunya adalah kolam renang di bungalowpark "Selecta" (sekarang Taman Rekreasi Selecta) di Batu, Malang (Gambar 22). Taman rekreasi ini didirikan oleh F. de Ruijter de Wildt pada tahun 1928 dan resmi dibuka pada tahun 1933.23 Selain kolam renang, Selecta juga dilengkapi dengan bungalow dan hotel. Kondisi kolam renang saat ini telah mengalami perubahan. Kolam renang diperlebar dan dibangun beberapa bangunan tambahan serta seluncuran. Meskipun demikian bangunan lamanya masih dipertahankan (Gambar 23).

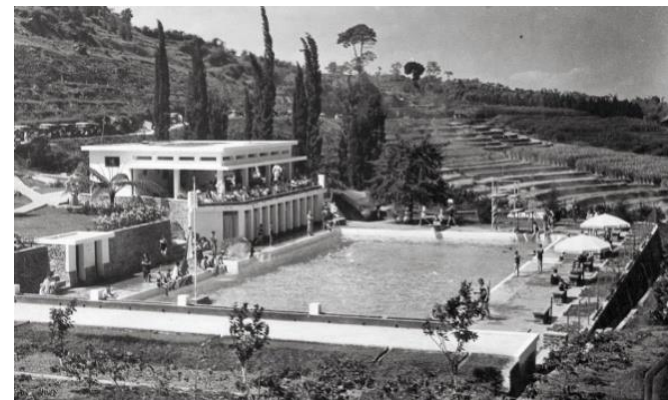

Gambar 22. Kolam Renang Selecta, Malang Pada masa kolonial (Sumber: colonialarchitecture.eu)

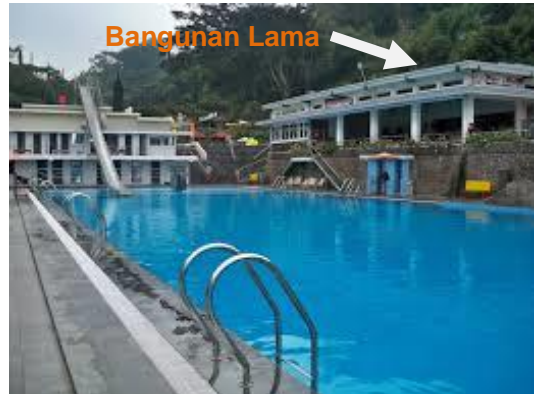

Gambar 23. Kolam Renang Selecta, Malang Kondisi tahun 2015

(Sumber: hotelmurahku.com)

22 Sumber: https:// www.poolspanews.com/business/the-history-of-concrete-pools-the-peoples-pool_o

${ }_{23}^{3}$ Soerabaijasch Handelsblad, "Selecta's Openingfeest", 6 November 1933; De Indische Courant, "Nieuw zwembak te Poenten", 25 Oktober 1933 


\section{DISKUSI DAN PEMBAHASAN}

\section{Perkembangan Penggunaan Beton Bertulang Pada Masa Kolonial}

Perkembangan penggunaan beton bertulang selama masa kolonial tidak dapat dipisahkan dari faktor-faktor yang mendorong perkembangan beton bertulang itu sendiri. Berikut ini adalah beberapa faktor-faktor yang mendorong perkembangan beton bertulang:

\section{Tenaga ahli konstruksi}

Kebutuhan tenaga ahli konstruksi, insinyur sipil dan arsitek meningkat bersamaan dengan kegiatan pembangunan di Hindia Belanda pada awal abad ke-20 (Koesno, 2012, hlm. 13-15). Hal ini mendorong pemerintah kolonial untuk mendatangkan insinyur sipil dan arsitek dari Belanda karena jumlah tenaga ahli yang terbatas. Tenaga-tenaga ahli ini dibutuhkan dalam dinas-dinas pemerintah seperti Department van B.O.W. dan Dienst der Gemeentewerken 24 . Tenaga-tenaga ahli tersebut, banyak yang mengembangan usaha konstruksi swasta di Hindia Belanda seperti biro arsitek-sipil (architecten-ingenieurs bureau) atau kontraktor bangunan (bouwaanemers) disamping bekerja pada dinas pemerintah.

Keberadaan tenaga ahli konstruksi terutama insinyur sipil berperan penting dalam perkembangan beton bertulang pada masa kolonial. Mereka umumnya merupakan lulusan dari Technische Hogeschool Delft-T.H. Delft ${ }^{25}$. Beton bertulang sendiri mulai dimasukkan ke dalam kurikulum teknik sipil di T.H. Delft pada tahun 1905 (Heinemann, 2013, hlm. 46-47). Insinyur sipil berperan penting di balik berdirinya sebuah konstuksi beton bertulang, meskipun mereka kurang begitu dikenal. Insinyur sipil memeriksa kekuatan struktur bangunan yang dirancang arsitek, menghitung dan menentukan ukuran elemen-elemen struktur, tulangan, spesifikasi material, termasuk menentukan pentahapan konstruksinya, seperti ukuran bekisting dan teknik pengecoran (Frick, dkk., 2004, hlm. 203-204). Peran insinyur sipil lebih menonjol dalam perancangan infrastruktur seperti menara air, jembatan dan bendungan.

Pesatnya kegiatan pembangunan di Hindia Belanda meningkatkan kebutuhan insinyur sipil, sehingga mendorong dibukanya institusi pendidikan setingkat T.H. Delft di Hindia Belanda yaitu Technische Hoogeschool te Bandoeng - T. H. Bandoeng pada 3 Juli 1920. Kurikulum yang digunakan di T. H. Bandoeng disesuaikan dengan kurikulum di T. H. Delft, demikian juga dengan lulusannya dianggap setara dengan lulusan dari T. H. Delft (Eryudhawan, 2012, hlm. 82). Sejumlah insinyur sipil bumiputera tercatat merupakan lulusan dari T. H. Bandoeng (sekarang Institut Teknologi Bandung) seperti Ir. Soekarno, Ir. Rooseno Soejohadikoesomo dan Ir. Sedijatmo Atmohoedojo.

\section{Ketersediaan material bangunan}

Material-material yang digunakan dalam pembuatan beton bertulang di masa kolonial dan sekarang tidak jauh berbeda seperti semen Portland, pasir,

\footnotetext{
${ }^{24}$ Dienst der Gemeentewerken - Dinas Pekerjaan Kota merupakan dinas yang berada di bawah pemerintah kota yang bertugas untuk merencanakan pembangunan kota (Akihary, 1990, pp. 27-28)

${ }^{25}$ Sebelumnnya bernama Polytechnische School van Delft (1864-1905). Pada 1905 statusnya ditingkatkan menjadi perguruan tinggi dengan kurikulum yang disesuaiakan kemudian menjadi Technische Hogeschol Delft (1934).
} 
batu pecah (split) atau kerikil, batangan besi-baja untuk tulangan (reinforcing barrebar), serta air (Gambar 24). Semen Portland dan besi-baja merupakan material yang dihasilkan melalui pabrik pengolahan (industri) sehingga jumlah yang tersedia pada waktu itu relatif terbatas, sementara pasir dan batu pecah dapat diperoleh secara lokal dan jumlahnya relatif berlimpah (Gunawan, 1994, hlm. 64).
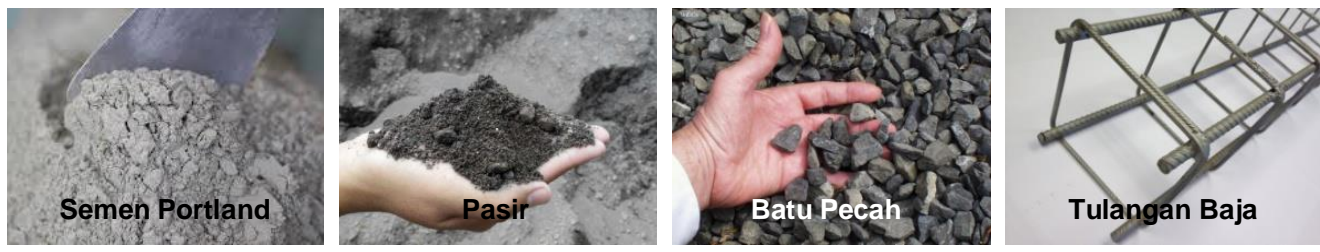

Gambar 24. Material-Material Penyusun Beton Bertulang

(Sumber: lafarge.ca, inspiradata.com, buildersserve.com, lemon-gs.co.uk)

Kebutuhan material besi-baja masih bergantung pada impor karena sampai akhir masa kolonial belum ada industri pengolahan besi-baja di Hindia Belanda. Besi-baja diimpor dari dari Jerman, Inggris dan Amerika Serikat sehingga fluktuasi harga baja-besi di pasaran dunia turut berpengaruh pada biaya konstruksi. ${ }^{26}$ Besi lebih banyak digunakan sebagai tulangan pada awalnya, namun besi lebih cepat mengalami korosi (Reed, dkk., 2008, hlm. 9), sehingga digantikan dengan tulangan dari baja. Baja memiliki kekuatan dan daktilitas $^{27}$ (ductility) yang lebih tinggi dibandingkan besi dan lebih tahan terhadap korosi atau karat.

Semen Portland pada awalnya merupakan material yang diimpor di Hindia Belanda. Berdasarkan iklan yang terdapat dalam surat kabar, semen Portland sudah dipasarkan pada 1880-an. Semen Portland yang ada pada waktu itu merupakan semen yang diimpor dari Jerman, Belgia, Belanda, Inggris dan Amerika Serikat ${ }^{2}$. Pabrik semen di Hindia Belanda, NederlandscheIndische Portland Cement Maatschappij (N.I. Portland Cement) atau lebih dikenal Padang Portland Cement baru didirikan di Indarung, Padang, Sumatera Barat pada tahun 1910. Produk Padang Portland Cement memenuhi standar semen Portland yang ditetapkan Department van B.O.W. dan dipasarkan dengan merk "Karbouw" (kerbau). Produksi Padang Portland Cement menyuplai sebagian besar kebutuhan semen di Hindia Belanda. N.I. Portland Cement Mij. kemudian menjadi PT Semen Padang adalah satu-satunya pabrik semen di Indonesia sampai tahun 1958.

\section{Peralatan dan teknik pengecoran}

Peralatan yang digunakan dalam konstruksi beton bertulang di masa kolonial pada umumnya masih dioperasikan oleh tenaga manusia (manual). Peralatan yang digunakan antara lain: pengaduk beton (betonmolen/mixer concrete), pengerek, pemadat manual seperti tongkat kayu (disebut juga pencocok), perata, penuang serta dibutuhkan cetakan beton yang biasanya disebut bekisting (beton bekisting) dan perancah (steiger/ scaffolding).

\footnotetext{
${ }^{26}$ Bataviaasch nieuwsblad, "Invoer van 60.000 Ton Ijzer en Staal verzekerd", 1 Februari 1918.

27 Daktilitas merupakan kemampuan suatu material untuk berubah bentuk (deformasi) seperti meregang atau menekuk ketika merespon tegangan.

${ }_{28}$ Berdasarkan iklan dari surat kabar: Het nieuws van den dag voor Nederlandsch-Indië, 25 Juni 1910; Bataviaasch Nieuwsblaad, 7 Maret 1908; Bataviaasch Nieuwsblaad, 13 Desember 1910; Bataviaasch Nieuwsblaad, 11 Juni 1910.
} 
Fungsi bekisting adalah untuk menampung dan membentuk beton bertulang tetap di tempatnya sampai mengering (Frick, dkk., 2004, hlm. 203-204). Bekisting berupa papan-papan dari kayu biasanya ditopang dengan perancah (penyangga) yang terbuat dari bambu agar bekisting dapat didirikan. Perancah juga berfungsi sebagai area kerja (work space) untuk bagian-bagian yang sulit dijangkau (tinggi). Pemasangan bekisting dan perancah harus diperhitungkan dengan benar karena papan dapat mengembang apabila terkena hujan atau panas, sehingga akan berpengaruh terhadap bentuk yang dihasilkan. Penggunaan perancah bambu dan kayu saat ini mulai digantikan dengan pipa-pipa besi, sementara penggunaan papan-papan dari kayu digantikan dengan multipleks yang lebih ekonomis.

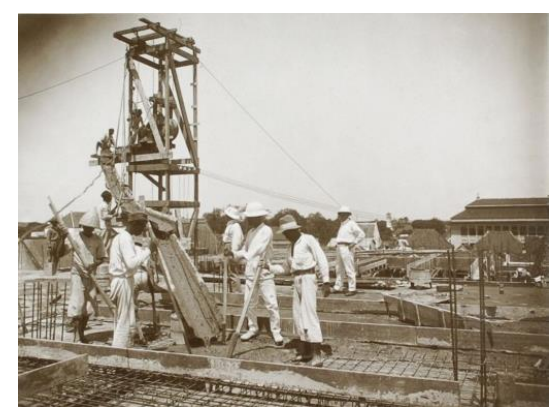

Gambar 25. Penuangan Beton dengan Peralatan Sederhana

(Sumber: colonialarchitecture.eu)

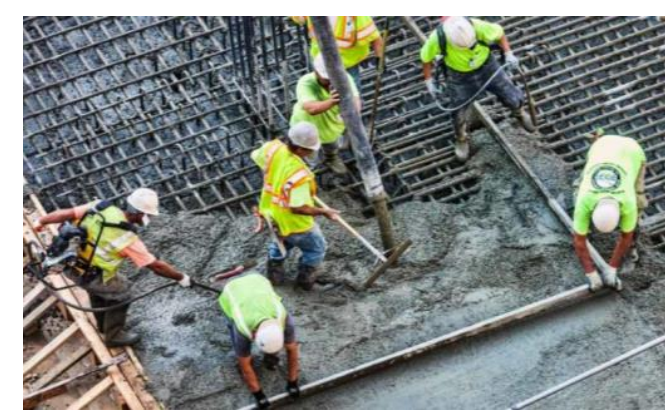

Gambar 26. Penuangan Beton dengan Peralatan Masinal - Beton dialirkan melalui selang (Sumber: exaktime.com)

Pengadukan beton dilakukan dengan tangan atau dengan alat pengaduk, betonmolen. Pengadukan beton dikerjakan di lokasi konstruksi (on site) karena beton memiliki waktu terbatas sehingga harus segera dituang setelah diaduk sebelum mengeras. Penuangan beton masih menggunakan peralatan sederhana, beton dikerek ke tempat yang lebih tinggi kemudian dialirkan melalui penuang dari besi, kedalam cetakan (Gambar 25). Beton yang sudah berada di dalam cetakan selanjutnya dipadatkan dengan alat pemadat manual. Pencocok ditusuktusukkan ke dalam cetakan agar beton dapat masuk sampai ke celah-celah tulangan supaya tidak ada udara-ruang kosong (Frick, dkk., 2007, hlm. 97-98). Beton basah yang telah dicetak ke dalam bekisting dalam beberapa waktu akan mengeras dan memasuki masa perawatan. Perkembangan peralatan masinal seperti concrete mixer truck atau agitator truck, concrete pump, tremie (untuk pengecoran di dalam air) dan vibrator (alat pemadat) membuat pekerjaan pengecoran sekarang menjadi lebih mudah (Gambar 26).

\section{Berkembangnya perusahaan konstruksi (bouwbedrijf)}

Bersamaan dengan meningkatnya kegiatan pembangunan, kontraktor bangunan (aanemers) tumbuh subur di Hindia Belanda antara tahun 1910-an sampai 1930-an. Bermunculan kontraktor-kontraktor yang menangani konstruksi beton bertulang dalam kurun waktu tersebut yang umumnya didominasi oleh perusahaan konstruksi swasta Belanda (bouwbedrijf) seperti Hollandsche Beton Maatschappij (H.B.M), Nederlandsche Aanemings Maatschappij (NEDAM), Volker Aanemings Maatschappij, Aaneming Maatschappij "De Kondor", Bouwkundig Bureau 
Sitsen $\mathcal{E}$ Louzada dan Aaneming Maatschappij Ooiman $\mathcal{E}$ van Leeuwen. Kombinasi biro arsitek swasta (architecten bureau)-kontraktor bangunan (Akihary, 1990, hlm. 29).

Biro arsitek ${ }^{29}$ yang merangkap kontraktor bangunan turut berkembang pada waktu itu. Beberapa kombinasi biro arsitek-kotraktor diantaranya adalah Algemeen Ingenieurs en Architecten-bureau (A.I.A.), Architecten-Ingenieurs en Aanemersbedrijf Associatie Selle $\mathcal{E}$ de Bruyn Reyerse $\mathcal{E}$ de Vries, Job en Sprey Architecten en Ingenieurs-bureau, Ingenieurs en Architecten-bureau Bond $\mathcal{E}$ Ogilvie (Gambar 27). Perusahaan konstruksi Belanda hanya beroperasi antara tahun 1947 sampai menjelang tahun $1960 .{ }^{30}$
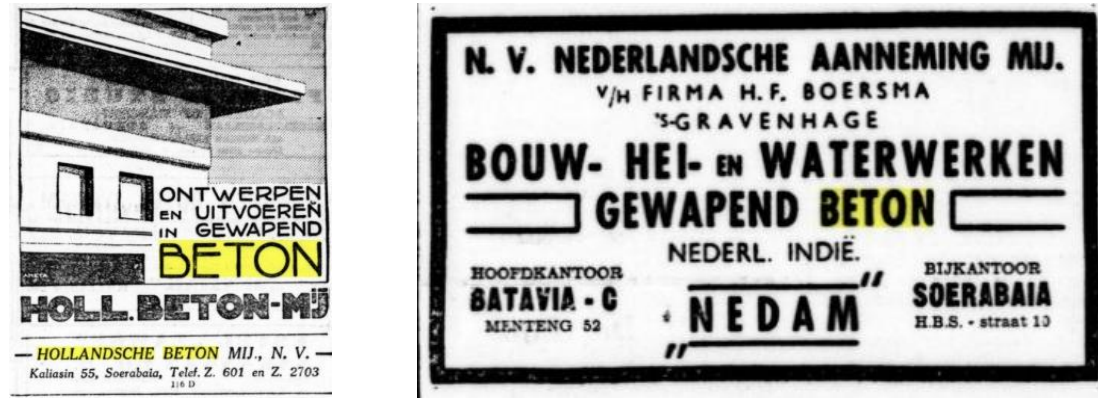

Gambar 27. Iklan H.B.M dan NEDAM dalam Surat Kabar

(Sumber: Soerabaijasch Handelsblad 1932/1935)

Kontraktor bangunan kecil dan menengah yang dijalankan perorangan atau kelompok sudah berkembang pada waktu itu. Lulusan Hoogere Burger School (H.B.S.) atau insinyur sipil dari T. H. Bandoeng yang memiliki latar belakang pendidikan di bidang konstruksi biasanya dapat membuka usaha kontraktor. Kontraktor bangunan dalam skala ini tidak hanya dijalankan oleh orang Belanda dan Tionghoa, namun juga Bumiputra. Proyek-proyek yang ditangani umumnya adalah pekerjaan kecil hingga menengah dan jangkauannya masih regional (terbatas pada daerah). Kontraktor kecil dan menengah biasanya juga menjadi sub kontraktor (onder-aanemers) dari kontraktor besar (Kartiwan, dkk., 2010, hlm. 26).

\section{KESIMPULAN}

Teknologi beton yang berkembang di Indonesia pasca kemerdekaan sampai sekarang merupakan kelanjutan dari perkembangan beton bertulang di masa kolonial. Bangunan-bangunan dan infrastruktur beton bertulang yang masih ada sampai sekarang menunjukan majunya teknologi (konstruksi) beton yang berkembang pada masa itu. Perkembangan penggunaan beton bertulang tidak hanya menggambarkan perkembangan teknologi konstruksi, tetapi juga kondisi sosial dan ekonomi pada masa kolonial.

\footnotetext{
${ }^{29}$ Biro arsitek tidak selalu bertindak sebagai pelaksana konstruksi. Dalam beberapa kasus perancangan dilakukan oleh biro arsitek dan eksekusi dilaksanakan oleh perusahaan konstruksi. Sebagai contoh bangunan kantor NILLMIJ di Yogyakarta yang rancangannya dibuat oleh F. J. L. Ghijsels dari biro A.I.A. sementara eksekusinya diserahkan kepada Sitsen \& Louzada.

${ }^{30}$ Pemerintah Indonesia pada tahun 1958 mulai mengeluarkan peraturan-peraturan terkait dengan nasionalisasi perusahaan-perusahaan milik Belanda yang ada di Indonesia. Berdasarkan Peraturan Pemerintah Republik Indonesia Nomor 2 Tahun 1960 Tentang Penentuan Pemborongan Milik Belanda yang Dikenakan Nasionalisasi, terdapat sembilan perusahaan konstruksi Belanda yang dinasionalisasi.
} 


\section{DAFTAR PUSTAKA}

Ahmad, Tantra. (2018). Kantor Pos Besar Bandung, Sejarah yang Tidak Bisa

Dihancurkan. Diunduh dari http://www.infobdg.com/v2/kantor-posbesar-bandung-sejarah-yang-tidak-bisa-dihancurkan/

Akihary, H. (1990). Architectuur E Stedebouw in Indonesië 1870/1970. Revised ed. Zutphen: De Walburg Pers.

Artanegara. (2017). Jembatan Kampung Tingkgi Dibangun Sekitar Abad 18 Masehi. Diunduh dari https://kebudayaan.kemdikbud.go.id/bpcbbali/jembatan-kampungtinggi-dibangun-sekitar-abad-18-masehi/

Association, B. C. (1999). Concrete Through the Age: From 7000 BC to AD 2000. First ed. Berkshire: British Cement Association.

Bataviaasch nieuwsblad, "De Krojalijn", 6 Maret 1915.

Bataviaasch nieuwsblad, "Invoer van 60.000 Ton Ijzer en Staal verzekerd", 1 Februari 1918.

Bataviaasch nieuwsblaad, "Station Batavia", 30 Januari 1928.

Bataviaasch nieuwsblaad, "Het New Station Batavia", 4 Oktober 1929.

De Indische Courant, "Nieuw zwembak te Poenten", 25 Oktober 1933

De Locomotief: Samarangsch handels- en advertentie-blad, "Nieuw Metsel-Materiaal", 24 Desember 1869.

De Preanger Bode, "De Opening van Pasar Baroe", 7 September 1915.

De Preanger Bode, "Gemeentewerken", 21 Oktober 1915.

Eryudhawan, B. (2012). Sukarno Bapak Arsitek Indonesia. Dalam: Pusat Dokumentasi Arsitektur (Ed.), Tegang Bentang: Seratus Tahun Perspektif Arsitektural di Indonesia. Jakarta: Gramedia Pustaka Utama.

Frick, H. (1996). Arsitektur dan Lingkungan. Yogyakarta: Kanisius.

Frick, H. (1997). Pola Struktural dan Teknik Bangunan di Indonesia. Yogyakarta: Kanisius.

Frick, H. \& Moediartianto. (2004). Ilmu Konstruksi Bangunan Kayu: Pengantar Konstruksi Kayu. Yogyakarta: Kanisius.

Frick, H. \& Setiawan, P. L. (2007). Ilmu Konstruksi Struktur Bangunan: Cara Membangun Kerangka Gedung. Yogyakarta: Kanisius.

Gunawan, R. (1994). Pengantar Ilmu Bangunan. Yogyakarta: Kanisius.

Harrer, A. \& Gaudette, P. (2017). Assesment of Historic Structures. APT Bulletin: The Journal of Preservation Technology, 48(4), 29-36.

Heinemann, H. A. (2013). Historic Concrete: From Concrete Repair to Concrete Conservation. Delftdigitalpress. 
Het nieuws van den dag voor Nederlandsch-Indie," "De eerste brug van gewapend beton", 14 Mei 1906.

Het nieuws van den dag voor Nederlandsch-Indie," "Gewapend Beton Spoorbruggen in de S.S. Lijnen", 24 November 1916.

Het nieuws van den dag voor Nederlandsch-Indie," "De irrigatie-werken bij Krawang", 2 April 1924.

Het nieuws van den dag voor Nederlandsch-Indie," "De irrigatie-werken bij Krawang", 28 April 1925.

Het nieuws van den dag voor Nederlandsch-Indie," "Het ernstig defect in da Tjitaroemirrigatiewerken", 24 April 1929.

Java-bode : nieuws, handels- en advertentieblad voor Nederlandsch-Indie, "Beton", 2 Juni 1870.

Kartiwan, I., Soenardji, H. \& Katuuk, K. A. (2010). Wajah Jasa Konstruksi Indonesia: Tinjauan Keberpihakan. Jakarta: PT. Gramedia Pustaka Utama.

Koesno, A. (2009). Gaya Imperium yang Hidup Kembali Setelah Mati: Arsitektur Indis dan Art Deco. Dalam: P. J. Nas \& M. de Vletter (Ed.). Masa Lalu dalam Masa Kini: Arsitektur di Indonesia. Jakarta: Gramedia.

Koesno, A. (2012). Zaman Baru Generasi Modernis: Sebuah Catatan Arsitektur. Yogyakarta: Penerbit Ombak.

Lemei, W. (1934). Moderne Woning-Architectuur in Ned. Indie. Bandoeng: G. Kolff \& Co.

McCormac, J. C. (2004). Desain Beton Bertulang Jilid I (Edisi Kelima, Bahasa Indonesia). Jakarta: Erlangga.

Mrázek, R. (2006). Engineers od Happy Land: Perkembangan Teknologi dan Nasionalisme di sebuah Koloni. Jakarta: Yayasan Obor Indonesia.

Mishra, Gopal. (Tanpa tahun). 23 Types of Concrete and Their Applications. Diunduh dari https://theconstructor.org/concrete/types-concreteapplications/19779/

Ommen, v. (1938). Verbreeding van de Petissahbrug te Medan. Locale Techniek, 7(5), 119-120.

Passchier, C. (2009). Arsitektur Kolonial di Indonesia. Dalam: P. J. Nas \& M. de Vletter (Ed.). Masa Lalu dalam Masa Kini Arsitektur di Indonesia. Jakarta: Gramedia Pustaka Utama.

Passchier, C. (2012). Mencari Arsitektur Indonesia yang Utama pada Masa Akhir Kolonial. Dalam: Pusat Dokumentasi Arsitektur (Ed.). Tegang Bentang: Seratus Tahun Perspektif Arsitektural di Indonesia. Jakarta: Gramedia Pustaka Utama.

Peraturan Pemerintah Republik Indonesia Nomor 2 Tahun 1960 Tentang Penentuan Pemborongan Milik Belanda Yang Dikenakan Nasionalisasi. 
Roberts, A. (Tanpa tahun). Where the Système Hennebique Lives On. Diunduh dari http://parisisinvisible.blogspot.com/2011/10/where-systemehennebique-lives-on.html

Robledo, R. (2012). The History of Concrete Pools: The People's Pool. Diunduh dari https://www.poolspanews.com/business/the-history-of-concretepools-the-peoples-pool_o

Semarang, Gemeente. (1931). Gedenkboek der gemeente Semarang 1906-1931. Semarang: N. V. Dagblad de Locomotief.

Setijono, A. (2015). Hentikan Perusakan Bangunan Cagar Budaya Pasar Peterongan Semarang. Diunduh dari https://www.change.org/p/hentikan-perusakan-bangunan-cagarbudaya-pasar-peterongan-semarang

Sukendar, H., Simanjuntak, T. \& Eriawati, Y. (1999). Metode Penelitian Arkeologi. Jakarta: Pusat Penelitian Arkeologi Nasional.

Soerabaijasch Handelsblad, "Selecta's Openingfeest", 6 November 1933.

Soerabaijasch Handelsblaad, "Bestaande Irrigatiewerken", 23 Oktober 1937.

Tanpa nama. (2016). Moojen Mengubah Dunia. Diunduh dari http://tarulh.com/2016/04/04/moojen-mengubah-batavia/

van Romondt, V. R. (2009). Pemugaran Candi Siva di Prambanan. Dalam: R. Jordaan (Ed.). Memuju Prambanan: Bunga Rampai Para Cendekiawan Belanda Tentang Kompleks Percandian Loro Jonggrang. Jakarta: Yayasan Pustaka Obor Indonesia - KITLV Jakarta.

Wibowo, A. (2017). Dampak Sosial Ekonomi Pembangunan Watertoren di Kota Magelang Tahun 1916-1926. Jurnal Ilmu Sejarah, 2(2), 164-178. Diunduh dari http://journal.student.uny.ac.id/ojs/index.php/ilmusejarah/article/view/8790 